\title{
PENGELOLAAN KAWASAN KARST DAN PERANANNYA DALAM SIKLUS KARBON DI INDONESIA
}

\author{
Ahmad Cahyadi \\ Jurusan Geografi Lingkungan \\ Fakultas Geografi, Universitas Gadjah Mada \\ ahmadcahyadi@geo.ugm.ac.id
}

\begin{abstract}
INTISARI
Karst adalah suatu istilah yang digunakan untuk menyebutkan suatu bentuklahan yang terbentuk oleh proses pelarutan (solusional). Kawasan karst di Indonesia memiliki luas kurang lebih 15,4 juta hektar. Namun demikian, kawasan ini memiliki peranan penting dalam siklus karbon di Indonesia, khususnya dalam proses penyerapan karbondioksida yang terjadi dalam proses karstifikasi atau pelarutan.

Peranan kawasan karst di Indonesia dalam penyerapan karbondioksida memiliki fungsi strategis berkaitan dengan adanya fenomena ITCZ (Intertropic Convergence Zone) yang menyebabkan adanya aliran masa udara menuju daerah tropis. Aliran ini berasal dari $30^{\circ}$ lintang utara dan $30^{\circ}$ lintang selatan yang tidak hanya membawa uap air, namun juga membawa berbagai gas rumah kaca dan polutan udara yang lain. Oleh karena itu, maka Indonesia membutuhkan penyerap karbondioksida yang cukup banyak agar jumlahnya di atmosfer tidak berlebihan dan menyebabkan berbagai dampak negatif. Selain itu, curah hujan di Indonesia yang tinggi memungkinkan terjadinya proses pelarutan yang intensif sehingga proses penyerapan karbondioksida dapat berjalan dengan baik. Berkaitan dengan hal di atas, maka pengelolaan kawasan karst melalui zonasi kawasan karst menjadi sangat penting untuk dilakukan, sehingga fungsi penyerapan karbondioksida di kawasan karst di Indonesia dapat terus berlangsung dengan baik.
\end{abstract}

Kata Kunci: Karst, Penyerapan Karbondioksida, Pengelolaan Kawasan Karst

Seminar Nasional Perubahan Iklim di Indonesia 13 Oktober 2010

Sekolah Pasca Sarjana UGM Yogyakarta Ahmad Cahyadi, Pengelolaan Kawasan Karst... 
Karst adalah sebuah istilah dalam Bahasa Jerman yang diturunkan dari Bahasa Slovenia yang berarti lahan gersang berbatu (Haryono dan Adji, 2004). Istilah tersebut sebenarnya menggambarkan kondisi yang sering ditemui di banyak daerah yang berbatuan karbonat atau batuan lain yang memiliki sifat mudah larut. Akibat terjadinya proses pelarutan (solusional/karstifikasi), maka terbentuklah suatu sistem hidrologi yang unik. Sistem hidrologi kawasan karst sangat dipengaruhi oleh porositas sekunder yang menyebabkan air masuk ke dalam sistem aliran bawah tanah dan menyebabkan kondisi kering di permukaan.

\section{Karbondioksida $\left(\mathrm{CO}_{2}\right)$ dan Pemanasan Global}

Karbondioksida adalah molekul yang tersusun atas unsur karbon dan oksigen. Karbondioksida $\left(\mathrm{CO}_{2}\right)$ merupakan salah satu penyebab pemanasan global selain beberapa gas lain seperti $\mathrm{CH}_{4}, \mathrm{CFC}, \mathrm{N}_{2} \mathrm{O}$, dan $\mathrm{O}_{3}$. Gas karbondioksida $\left(\mathrm{CO}_{2}\right)$ dipakai sebagai komparasi terhadap kenaikan temperatur akibat adanya kenaikan gas rumah kaca karena memberi kontribusi terbesar dalam pemanasan global yakni $50 \%$, sedangkan gas $\mathrm{CFC}$ berkontribusi sebesar 20\%, $\mathrm{CH}_{4}$ sebesar $15 \%, \mathrm{O}_{3}$ sebesar $8 \%$ dan $\mathrm{NO}_{\mathrm{x}}$ berkontribusi sebesar 7\% (Cahyono, 2009).

Meskipun karbondioksida $\left(\mathrm{CO}_{2}\right)$ berkontribusi paling besar, sebenarnya karbondioksida $\left(\mathrm{CO}_{2}\right)$ memilki nilai global warming potential (GWP) terkecil dibandingkan dengan gas rumah kaca yang lain (Adiningsih, 2009). Kontribusi yang besar disebabkan karena konsentrasinya terbesar dibandingkan gas rumah kaca yang lain, yakni mencapai 800 gigaton karbon di atmosfer (Sumaryati, 2009). Hal ini diantaranya disebabkan karena senyawa $\mathrm{CO}, \mathrm{CH}_{4}$, dan senyawa hidrokarbon non-metan lainnya pada akhirnya akan berubah menjadi karbondioksida $\left(\mathrm{CO}_{2}\right)$, misalnya karbonmonoksida $(\mathrm{CO})$ akan berubah menjadi karbondioksida $\left(\mathrm{CO}_{2}\right)$ setelah 2-3 bulan terbentuk.

\section{Keterkaitan Karst dan Karbondioksida $\left(\mathrm{CO}_{2}\right)$}

Penyerapan karbondioksida $\left(\mathrm{CO}_{2}\right)$ di kawasan karst terjadi pada proses karstifikasi. Proses ini diawali dengan larutnya karbondioksida $\left(\mathrm{CO}_{2}\right)$ di dalam air membentuk $\mathrm{H}_{2} \mathrm{CO}_{3}$. Larutan $\mathrm{H}_{2} \mathrm{CO}_{3}$ bersifat tidak stabil sehingga terurai menjadi $\mathrm{HCO}_{3}{ }^{2-}$ dan $\mathrm{H}^{+}$. Ion $\mathrm{H}^{+}$inilah yang kemudian akan menguraikan batugamping 
$\left(\mathrm{CaCO}_{3}\right)$ menjadi $\mathrm{Ca}^{2+}$ dan $\mathrm{HCO}_{3}{ }^{-}$. Proses karstifikasi berlangsung dengan kesetimbangan reaksi kimia tertentu, di mana setiap pelarutan 1 ton batugamping $\left(\mathrm{CaCO}_{3}\right)$ akan diikuti dengan penyerapan karbondioksida $\left(\mathrm{CO}_{2}\right)$ sebanyak 0,12 ton dari atmosfer (Gambar 1). Berikut ini adalah reaksi yang terjadi pada proses pelarutan batu gamping:

$$
\mathrm{H}_{2} \mathrm{O}+\mathrm{CO}_{2}+\mathrm{CaCO}_{3} \longrightarrow \mathrm{Ca}^{2+}+\mathrm{HCO}_{3}^{-}
$$

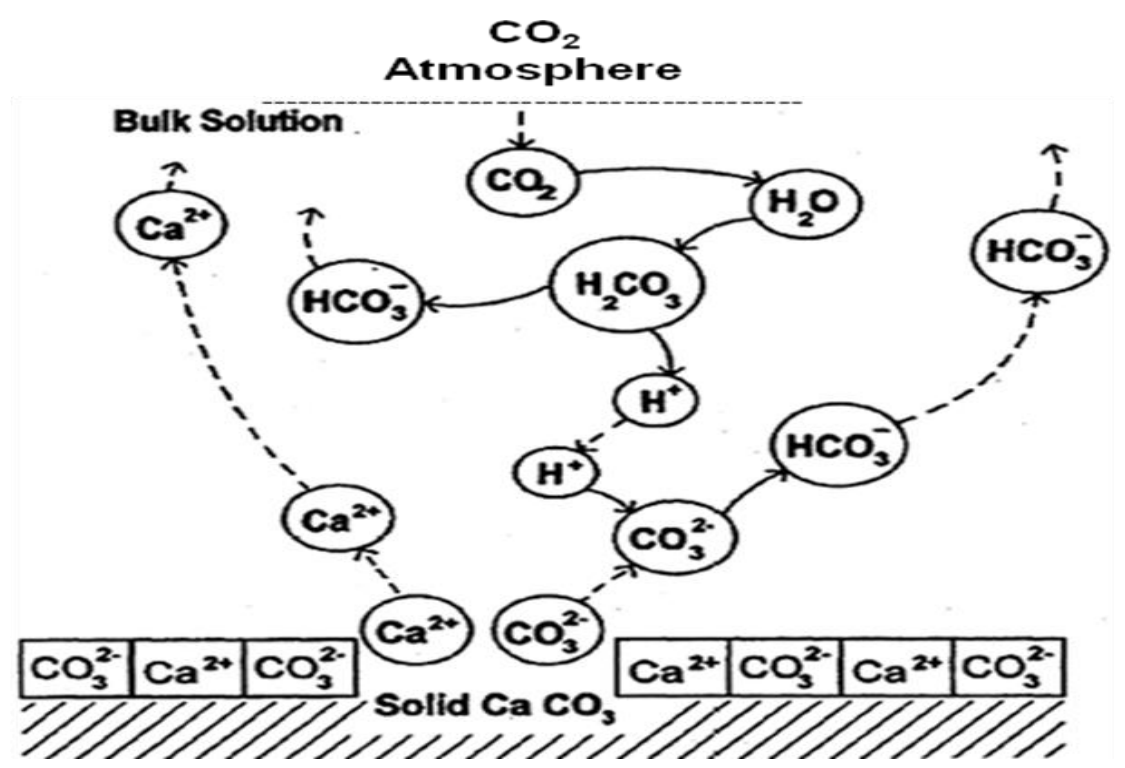

Gambar 1. Penyerapan karbondioksida $\left(\mathrm{CO}_{2}\right)$ dari atmosfer pada proses pelarutan batu gamping, di mana setiap pelarutan 1 ton batu gamping akan diikuti penyerapan karbondioksida $\left(\mathrm{CO}_{2}\right)$ sebesar 0,12 ton dari atmosfer (Adji, 2009)

\section{Perhitungan Karbondioksida yang Terserap dari Atmosfer oleh Proses Pelarutan Batuan Karbonat}

Peranan kawasan karst dalam penyerapan karbondioksida pertama kali diperkenalkan dalam program dari UNESCO/IUGS IGCP 299 dengan tema program "Geologi, Iklim, Hidrologi dan Formasi Karst” pada tahun 1990-1994, dan kemudian diteruskan dalam UNESCO/IUGS IGCP 379 yang bertemakan “Karstifikasi dan Siklus Karbon" pada tahun 1995-1999 (Daoxian, 2002). Pedoman IGCP 299 adalah untuk menginvestigasi morfologi karst dan hubungannya dengan 
kondisi lingkungan seperti; air, panas, energi kimia dan bioenergi serta kemudian menentukan mekanisme fisika-kimia dari bentukkan karst. Kesimpulan dari IGCP 299 mengindikasikan bahwa studi karst bisa sangat membantu untuk memahami siklus karbon global dan dengan demikian dapat berkontribusi lebih jauh untuk memahami perubahan global. Oleh karena itu, maka kemudian muncul program kedua yakni UNESCO/IUGS IGCP 379 yang bertujuan untuk:

a. Untuk menghitung kontribusi dari batuan karbonat dan proses-proses di kawasan karst untuk mengisi $\mathrm{CO}_{2}$ di atmosfer;

b. Untuk membandingkan keseimbangan $\mathrm{CO}_{2}$ tahunan antara atmosfer dan sistem karst dalam lingkungan geologi, iklim, dan ekologi yang berbeda;

c. Untuk menentukan asal mula dan jumlah emisi $\mathrm{CO}_{2}$ tahunan ke dalam atmosfer dari kawasan karst dengan aktivitas geotermal atau volkanik atau patahan aktif, terutama di daerah dekat dengan batas lempeng;

d. Untuk menyediakan informasi tentang proses-proses perubahan lingkungan setelah akhir pleistoisen dalam sebagian besar kawasan karst dunia, terutama pada suatu wilayah dengan tanpa bagian lingkungan masa lalu.

Hasil penelitian yang dikeluarkan dari program tersebut diantaranya adalah bahwa penyerapan karbon tahunan secara global dari atmosfer oleh proses karstifikasi diperkirakan sekitar $1,5 \times 10^{9}$ ton per tahun, dan karst di China berkontribusi sebesar $9,46 \times 10^{8}$ ton per tahun (Daoxian, 2002). Perhitungan tersebut dilakukan dengan menggunakan persamaan sebagai berikut:

$$
\mathrm{C}=Q \cdot\left[\frac{\mathrm{HCO}_{3}}{2} \times \frac{12}{61}\right]
$$

Seminar Nasional Perubahan Iklim di Indonesia 13 Oktober 2010 Sekolah Pasca Sarjana UGM Yogyakarta Ahmad Cahyadi, Pengelolaan Kawasan Karst... 
Keterangan:

C =Volume karbondioksida yang terserap dalam proses karstifikasi $\left(\mathrm{m}^{3} /\right.$ year $\left./ \mathrm{km}^{2}\right)$

Q = Runoff per desa (Presipitasi - Evaporasi) $(\mathrm{dm})$

$\mathrm{HCO}_{3}=$ Konsentrasi $\mathrm{CaCO}_{3}$ dalam air yang keluar melalui mata air (mg/l)

\section{Fungsi Strategis Kawasan Karst Indonesia}

Kawasan karst di Indonesia memiliki fungsi yang sangat strategis dalam penyerapan karbondioksida $\left(\mathrm{CO}_{2}\right)$. Hal tersebut berkaitan dengan posisi Indonesia yang terletak di kawasan tropis, di mana terpengaruh sistem gerakan atmosfer secara global. Gerakan atmosfer secara global yang berpengaruh terhadap kadar karbondioksida $\left(\mathrm{CO}_{2}\right)$ di wilayah tropis diantaranya adalah gerakan yang ditimbulkan oleh fenomena intertropical convergence zone (ITCZ). Keberadaan ITCZ menyebabkan terjadinya gerakan massa udara dari $30^{\circ} \mathrm{LU}$ dan $30^{\circ} \mathrm{LS}$ menuju wilayah tropis. Hal tersebut tentunya tidak hanya membawa massa udara saja, tetapi membawa uap air, gas-gas penyebab efek rumah kaca dan lain-lain. Oleh karena itu, penyerapan karbondioksida $\left(\mathrm{CO}_{2}\right)$ oleh kawasan karst di daerah tropis menjadi sangat penting dalam upaya mencegah atau mengurangi dampak pemanasan global akibat konsentrasi karbondioksida $\left(\mathrm{CO}_{2}\right)$ yang berlebihan.

Curah hujan menjadi faktor yang sangat berpengaruh terhadap proses karstifikasi. Karstifikasi hanya terjadi apabila kawasan batuan karbonat terletak pada wilayah dengan curah hujan lebih dari $250 \mathrm{~mm} / \mathrm{tahun}$, semakin besar curah hujannya maka proses karstifikasi akan berjalan dengan lebih intensif. Hal ini berarti bahwa proses karstifikasi di kawasan karst Indonesia akan berlangsung dengan sangat intensif karena Indonesia yang terletak di daerah tropis yang memiliki curah hujan tinggi. Pengaruh curah hujan terhadap kecepatan pelarutan batuan gamping dapat dilihat dari hasil penelitian yang dilakukan oleh Putro (2010) yang menyebutkan bahwa proses pelarutan yang terjadi di Kawasan Karst Jonggrangan, Kabupaten Kulon Progo dengan curah hujan rata-rata 2.516 $\mathrm{mm} /$ tahun ternyata lebih besar dibandingkan dengan kecepatan pelarutan yang

Seminar Nasional Perubahan Iklim di Indonesia 13 Oktober 2010 Sekolah Pasca Sarjana UGM Yogyakarta Ahmad Cahyadi, Pengelolaan Kawasan Karst... 
terjadi di Karst Gunungsewu di Kabupaten Gunungkidul, Wonogiri dan Pacitan yang memiliki curah hujan rata-rata curah hujan $2.051 \mathrm{~mm} / \mathrm{tahun}$. Hasil kajian terkait dengan laju pelarutan kawasan karst Gunungsewu dan Jonggrangan ditampilkan pada Tabel 1 .

Tabel 1. Laju Pelarutan Gamping

\begin{tabular}{|l|r|r|}
\hline \multicolumn{1}{|c|}{ Parameter } & \multicolumn{1}{c|}{$\begin{array}{c}\text { Karts } \\
\text { Jonggrangan }\end{array}$} & $\begin{array}{c}\text { Karst } \\
\text { Gunungsewu }\end{array}$ \\
\hline Hujan Wilayah (dm/tahun) & 25,16 & 20,51 \\
\hline Evapotranspirasi (dm) & 15,71 & 16,42 \\
\hline Run Off $(\mathrm{dm})$ & 9,45 & 4,09 \\
\hline Konsentrasi $\mathrm{CaCO}_{3}(\mathrm{mg} / \mathrm{l})$ & 215 & 218 \\
\hline Laju Pelarutan $\left.\mathrm{Gamping} \mathrm{(ton/tahun} / \mathrm{km}^{2}\right)$ & 42,97 & 18,86 \\
\hline
\end{tabular}

Sumber: Putro (2010)

Berdasarkan hasil penelitian di atas, maka kemudian dapat pula diperhitungkan jumlah penyerapan karbondioksida $\left(\mathrm{CO}_{2}\right)$ pada masing-masing wilayah. Penyerapan karbondioksida $\left(\mathrm{CO}_{2}\right)$ di Kawasan Karst Jonggrangan oleh proses pelarutan batu gamping adalah sebesar 5,16 ton $/$ tahun $/ \mathrm{km}^{2}$, sedangkan penyerapan karbondioksida $\left(\mathrm{CO}_{2}\right)$ di Kawasan Karst Gunungsewu oleh proses pelarutan batu gamping adalah sebesar 2,26 ton/tahun $/ \mathrm{km}^{2}$. Berdasarkan perhitungan tersebut, maka berarti bahwa Kawasan Karst Jonggrangan yang memiliki luas kurang lebih $25 \mathrm{~km}^{2}$ berpotensi menyerap karbondioksida $\left(\mathrm{CO}_{2}\right)$ sebesar 12.900 ton/tahun, sedangkan Kawasan Karst Gunungsewu yang memiliki luas $1.300 \mathrm{~km}^{2}$ berpotensi menyerap karbondioksida $\left(\mathrm{CO}_{2}\right)$ sebesar 293.800 ton/tahun.

\section{Permasalahan Kawasan Karst di Indonesia dan Pengaruhnya terhadap Penyerapan Karbondioksida $\left(\mathrm{CO}_{2}\right)$}

Fungsi penyerapan karbondioksida $\left(\mathrm{CO}_{2}\right)$ di kawasan karst di Indonesia dewasa ini menjadi terganggu, diantaranya akibat adanya penambangan batu gampig. Penambangan batu gamping di kawasan karst di Indonesia seringkali

Seminar Nasional Perubahan Iklim di Indonesia 13 Oktober 2010 Sekolah Pasca Sarjana UGM Yogyakarta Ahmad Cahyadi, Pengelolaan Kawasan Karst... 
dilakukan dengan cara overburden (pengelupasan) kerucut karst baik secara manual (dengan tenaga manusia) ataupun dengan menggunakan alat berat. Proses penambangan ini menyebabkan hilangnya lapisan epikarst pada batuan gamping sehingga proses karstifikasi tidak dapat terjadi (Gambar 2).

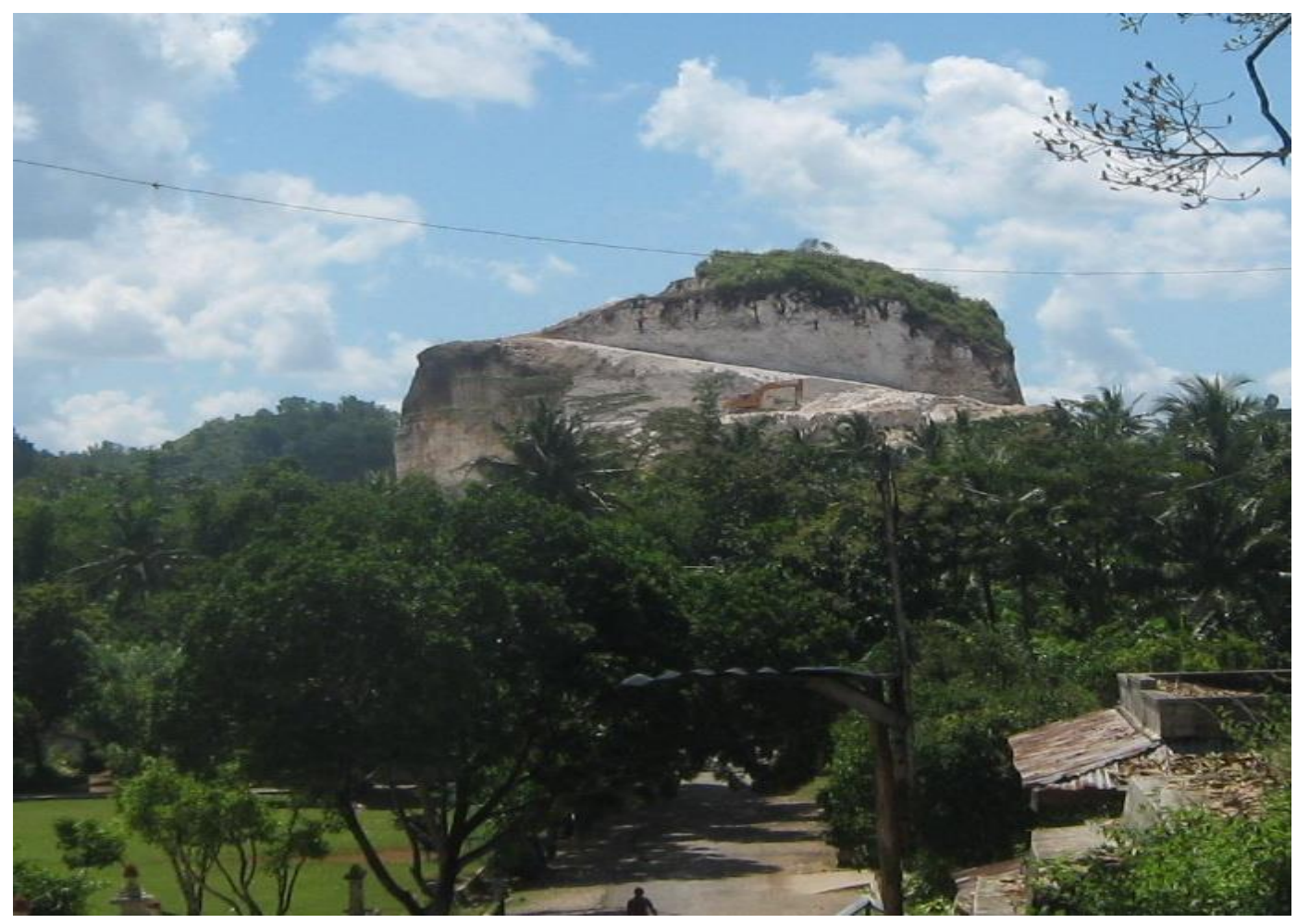

Gambar 2. Penambangan Batu Gamping di Bedoyo, Gunungkidul

(Ahmad Cahyadi, 2009)

Lapisan epikarst adalah lapisan tipis yang berda di bagian atas bamping yang terbentuk oleh tanah atau rekahan-rekahan yang mampu menyimpan air (Haryono, 2002). Proses karstifikasi sangat tergantung dengan keberadaan lapisan epikarst karena kemampuan meloloskan air batuan gamping rendah, sehingga dibutuhkan suatu lapisan penyimpan air yang berguna untuk menampung air selama belum terloloskan di dalam batuan gamping. Setelah air melewati pori-pori batuan gamping, maka proses karstifikasi baru akan dimulai. Ketiadaan lapisan epikarst akan menyebabkan air langsung mengalir sebagai aliran permukaan (runoff),

Seminar Nasional Perubahan Iklim di Indonesia 13 Oktober 2010 Sekolah Pasca Sarjana UGM Yogyakarta Ahmad Cahyadi, Pengelolaan Kawasan Karst... 
sehingga dalam waktu singkat akan mudah mengalami penguapan dan tidak menyebabkan terjadinya karstifikasi.

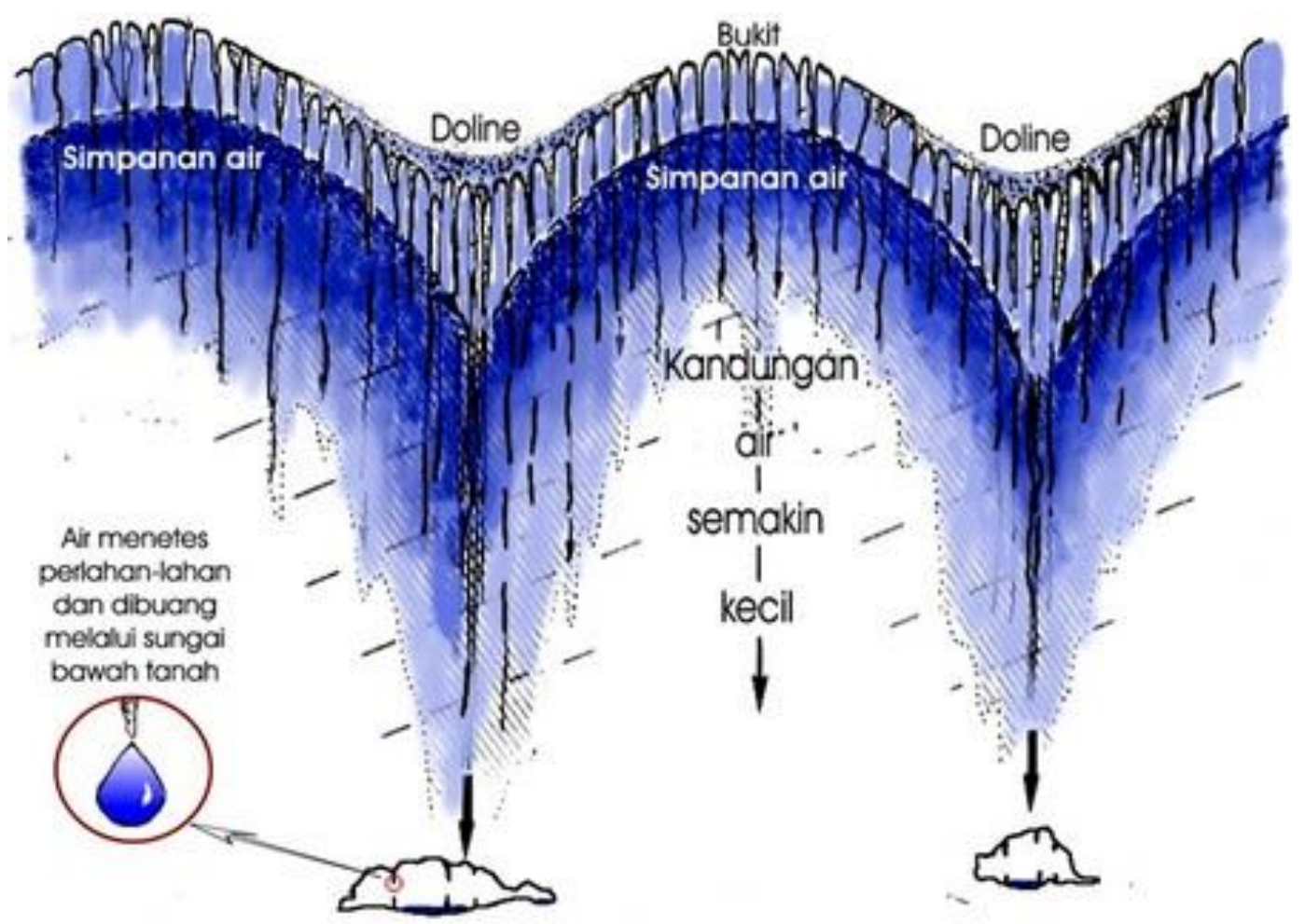

Gambar 3. Lapisan Epikarst (Haryono dan Adji, 2004)

\section{Pengelolaan Kawasan Karst sebagai Upaya Menjaga Fungsi Penyerapan Karbondioksida $\left(\mathrm{CO}_{2}\right)$}

Pengelolaan kawasan karst diartikan sebagai kegiatan yang meliputi inventarisasi, penyelidikan, pemanfaatan, dan perlindungan sumberdaya pada kawasan karst (Keputusan Menteri Energi dan Sumber Daya Mineral Nomor 1456 K/20/MEM/2000 tentang pengelolaan kawasan karst). Fungsi utama dari pengelolaan kawasan karst adalah untuk mengoptimalkan pemanfaatan kawasan karst guna menunjang pembangunan yang berkelanjutan dan berwawasan lingkungan.

Seminar Nasional Perubahan Iklim di Indonesia 13 Oktober 2010 Sekolah Pasca Sarjana UGM Yogyakarta Ahmad Cahyadi, Pengelolaan Kawasan Karst... 
Perlindungan kawasan karst di dunia pertama kali dimulai pada tahun 1997 oleh World Conservation Union (WCU) yang dahulu bernama Internasional Union for Conservation Nature (IUCN) yang bertujuan untuk melindungi daerah tangkapan air di kawasan karst (Ariyanto, 2006). Pengelolaan kawasan karst di Indonesia dilakukan sejak dikeluarkannya Surat Keputusan Menteri Pertambangan dan Energi Nomor 1518 K/20/MPE/1999 tanggal 29 September 1999, yang kemudian direvisi dengan Keputusan Menteri Energi dan Sumber Daya Mineral Nomor 1456 K/20/MEM/2000 tanggal 3 November 2000 mengenai pedoman pengelolaan kawasan karst. Hal yang paling membanggakan dalam sejarah pengelolaan kawasan karst di Indonesia adalah ketika pada tanggal 26-30 Mei 2001 Kawasan Karst Gunungsewu mendapatkan penghargaan dari Asia-pasific Forum on Karst Ecosystems and World Heritage sebagai World Natural Heritage.

Zonasi kawasan karst menjdia salah satu tahapan yang paling pening dalam pengelolaan kawasan karst. Hasil zonasi kawasan karst dapat digunakan sebagai suatu acuan dalam menentukan kegiatan pembangunan yang akan dilakukan di suatu kawasan karst. Salah satu dasar pemikiran pelaksanaan zonasi kawasan karst adalah karena tidak semua wilayah dengan batuan karbonat (gamping atau dolomit) dapat membentuk kawasan karst. Tingkat perkembangan karst pada batuan karbonat ditentukan oleh beberapa syarat berikut ini:

a. Terdapat batuan yang mudah larut, kompak, tebal dan mempunyai banyak retakan. Batuan yang mudah larut dapat berupa gamping, dolomit dan gipsum. Semakin tinggi kemurnian batuannya, maka proses pelarutan akan semakin baik. Pembentukkan topografi karst memerlukan minimal $50 \%$ kemurnian dari batuan yang terlarut, namun demikian proses karstifikasi akan berjalan baik apabila kandungan batuan yang mudah larut adalah lebih dari $90 \%$ tetapi kurang dari $96 \%$.

b. Memiliki curah hujan yang cukup tinggi. Faktor curah hujan menjadi sangat penting karena hujan merupakan media pelarut dalam proses karstifikasi. Oleh karena itu, maka semakin tinggi curah hujan maka proses pelarutan akan semakin intensif.

Seminar Nasional Perubahan Iklim di Indonesia 13 Oktober 2010 Sekolah Pasca Sarjana UGM Yogyakarta Ahmad Cahyadi, Pengelolaan Kawasan Karst... 
c. Batuan yang mudah larut terangkat di ketinggian yang memungkinkan perkembangan sirkulasi atau drainase secara vertikal. Syarat ini penting ada agar terjadi jarak yang cukup antara batuan gamping yang tidak jenuh air dengan muka airtanah, sehingga mampu terbentuk drainase air secara vertikal. Hal ini berarti bahwa semakin tinggi batuan karbonat terangkat, maka proses karstifikasi akan semakin intensif.

Wilayah dengan batuan karbonat yang tidak mengalami karstifikasi memiliki risiko pemanfaatan yang lebih kecil dibandingkan dengan kawasan karst yang berkembang dengan baik. Namun demikian, perlu pula dipertimbangkan fungsi suatu wilayah dalam perlindungan sumberdaya air, lingkungan budaya dan sejarah, serta perlindungan terhadap keberadaan makhluk hidup (baik tumbuhan ataupun hewan). Oleh karena itu dengan adanya zonasi kawasan karst ini maka kemudian dapat disusun suatu rencana pengelolaan lingkungan yang lebih baik. Misalnya dengan memindahkan lokasi penambangan batu gamping ke wilayah berbatuan gamping yang tidak mengalami karstifikasi atau proses karstifikasi berkembang tidak intensif, sehingga fungsi hidrologis dan penyerapan karbondioksida $\left(\mathrm{CO}_{2}\right)$ serta fungsi lindung lainnya tidak terganggu.

Proses zonasi kawasan karst dapat dilakukan dengan menggunakan teknologi penginderaan jauh untuk lebih mudah dalam melakukan delineasi suatu kawasan karst. Kawasan karst yang berkembang baik akan dicirikan dengan terbentuknya kerucut-kerucut karst atau menara karst, banyak dijumpai dolin dan memiliki topografi yang sangat kasar serta tidak diketemukan adanya sungai permukaan. Kawasan karst berkembang sedang dicirikan dengan bentukkan yang lebih halus dan mulai diketemukan aliran permukaan yang pendek dan hilang di suatu tempat (lembah buta). Meskipun demikian, proses ini harus ditindak lanjuti dengan menggabungkan dengan data spasial lain seperti peta geologi, peta rupa bumi, serta dilakukan survei lapangan untuk mengetahui tingkat kebenaran delineasi yang telah dilakukan.

Seminar Nasional Perubahan Iklim di Indonesia 13 Oktober 2010 Sekolah Pasca Sarjana UGM Yogyakarta Ahmad Cahyadi, Pengelolaan Kawasan Karst... 
Zonasi kawasan karst akan menghasilkan suatu peta tentang klasifikasi wilayah dalam tiga kelompok yakni Kawasan karst kelas I, II dan III. Berikut ini adalah penjelasan kriteria klasifikasi menurut Keputusan Menteri Energi dan Sumber Daya Mineral Nomor 1456 K/20/MEM/2000 tentang pengelolaan kawasan karst:

a. Kawasan Karst kelas I

Kawasan karst kelas I meliputi kawasan karst yang memiliki salah satu fungsi dari beberapa hal berikut:

1) Kawasan yang berfungsi sebagai kawasan penyimpan air secara tetap dalam bentuk akuifer, sungai bawah tanah, telaga, atau danau bawah tanah;

2) Kawasan yang memiliki gua-gua dan sungai-sungai bawah tanah yang aktif yang membentuk jaringan baik secara horisontal ataupun vertikal;

3) Kawasan yang memiliki gua-gua dengan speleothem (ornamenornamen gua) yang aktif atau peninggalan sejarah sehingga berpotensi dikembangkan sebagai objek wisata; atau

4) Kawasan yang memiliki flora dan fauna khas yang memenuhi arti dan fungsi sosial, ekonomi, budaya serta pengembangan ilmu pengetahuan.

b. Kawasan Karst Kelas II

Kawasan karst kelas II adalah kawasan karst yang tidak memiliki kriteria yang disebutkan dalam kawasan karst kelas I namun memiliki salah satu dari kriteria berikut ini:

1) Kawasan yang berfungsi sebagai pengimbuh air bawah tanah berupa daerah tangkapan air hujan yang mempengaruhi naik turunnya permukaan air bawah tanah kawasan karst sehingga secara umum masih mendukung fungsi hidrologi kawasan karst; atau

2) Kawasan yang berfungsi sebagai jaringan lorong-lorong bawah tanh hasil bentukan sungai dan gua yang sudah kering, serta menjadi

Seminar Nasional Perubahan Iklim di Indonesia 13 Oktober 2010

Sekolah Pasca Sarjana UGM Yogyakarta Ahmad Cahyadi, Pengelolaan Kawasan Karst... 
tempat tinggal yang tetap fauna yang semuanya dapat memberi nilai dan manfaat ekonomi.

c. Kawasan Karst Kelas III

Kawasan karst kelas III adalah kawasan yang tidak memiliki kriteria sebagaimana yang disebutkan dalam kawasan karst kelas I dan II.

\section{Rekomendasi}

Zonasi kawasan karst dalam mendukung pengelolaan kawasan karst saat ini belum dilakukan oleh semua pemerintah-pemerintah daerah di Indonesia yang memiliki kawasan karst sehingga penyusunan rencana pembangunan dan rencana tata ruang daerah belum mempertimbangkan kemungkinan untuk meminimalisir suatu dampak lingkungan akibat kegiatan pemanfaatan dan eksploitasi di kawasan karst. Mengingat pentingnya zonasi kawasan karst dalam pengelolaan kawasan karst dan menunjang pengelolaan lingkungan yang berkelanjutan, maka diperlukan suatu aturan yang mewajibkan dilakukannya proses zonasi kawasan karst dalam membuat rencana pemanfaatan kawasan karst atau rencana tata ruang wilayah yang berisi pula tentang standar-standar serta aturan-aturan teknis untuk melakukan zonasi tersebut yang lebih detail, sehingga pemanfaatan dan eksploitasi di kawasan karst dapat diminimalisir dampaknya, termasuk dapat menjaga fungsi hidrologis dan penyerapan karbondioksida $\left(\mathrm{CO}_{2}\right)$ serta fungsi lindung lainnya di kawasan karst di Indonesia. 


\section{DAFTAR PUSTAKA}

Adiningsih, E.S. 2009. Bencana Iklim di Indonesia Menjadi Agenda Sidang di UNCOPUOS-PBB. Media Dirgantara, 4(2): 4-9.

Adji, T.N. 2009. Atmospheric Carbondioxide Sequestration Trough Karst Denudation Process (Preliminary Estimation from Gunung Sewu Karst Area). Laporan Penelitian. Karst Research Group Faculty of Geography Gadjah Mada University.

Ariyanto, K.N. 2006. Pemberdayaan Masyarakat Kawasan Karst Gunung Sewu: Upaya Menuju World Natural Heritage. Laporan Penelitian. Sekolah Pasca Sarjana Ilmu Lingkungan Universitas Gadjah mada Yogyakarta.

Cahyadi, A. 2009. Zonasi Kawasan Karst di Indonesia sebagai Salah Satu Upaya Menjaga Penyerapan Karbondioksida. Makalah dalam Earth's Challenge di IPB Bogor, 5 Juni 2010.

Cahyono, E.W. 2009. Telah Terjadi Dampak Pemanasan Global Terhadap Ekosistem. Media Dirgantara, 4(2):14-17.

Daoxian, Y. 2002. The Carbon Cycle in Karst. IGCP Report.

Haryono, E. 2002. Laporan Akhir Zonasi Kawasan Karst Kabupaten Wonogiri. Laporan Penelitian. BAPPEDA Kabupaten Wonogiri dan Fakultas Geografi Universitas Gadjah Mada.

Haryono, E. dan Adji, T.N. 2004. Pengantar Geomorfologi dan Hidrologi Karst. Yogyakarta: Kelompok Studi Karst Fakultas Geografi Universitas Gadjah Mada.

Keputusan Menteri Energi dan Sumber Daya Mineral Nomor 1456 K/20/MEM/2000 tentang pengelolaan kawasan karst.

Putro, S.T. 2010. Laju Pelarutan Batuan Karbonat di Karst Gunungsewu dan Karst Jonggrangan. Skripsi. Fakultas Geografi Universitas Gadjah Mada.

Seminar Nasional Perubahan Iklim di Indonesia 13 Oktober 2010 Sekolah Pasca Sarjana UGM Yogyakarta Ahmad Cahyadi, Pengelolaan Kawasan Karst... 
Sumaryati. 2009. Meminimalisasi Dampak Gas Rumah Kaca dan Polusi Udara di Atmosfer. Media Dirgantara, 4(2):18-24.

Seminar Nasional Perubahan Iklim di Indonesia 13 Oktober 2010 Sekolah Pasca Sarjana UGM Yogyakarta Ahmad Cahyadi, Pengelolaan Kawasan Karst... 